\title{
Selective oxidative dehydrogenation of ethane to ethylene over a hydroxylated boron nitride catalyst
}

\author{
Lei Shi a, Bing Yan a, Dan Shao a, Fan Jiang a, Dongqi Wang b,\#, An-Hui Lu a,* \\ a State Key Laboratory of Fine Chemicals, School of Chemical Engineering, Dalian University of Technology, Dalian 116024, Liaoning, China \\ b Center for Multi-disciplinary Research, Institute of High Energy Physics, Chinese Academy of Sciences, Beijing 100049, China
}

\section{A R T I C L E I N F O}

Article history:

Received 9 January 2017

Accepted 18 January 2017

Published 5 February 2017

\section{Keywords:}

Boron nitride

Hydroxylation

Ethane

Oxidative dehydrogenation

Ethylene

\begin{abstract}
A B S T R A C T
Boron nitride containing hydroxyl groups efficiently catalysed oxidative dehydrogenation of ethane to ethylene, offering rather high selectivity (95\%) but only small amount of $\mathrm{CO}_{2}$ formation $(0.4 \%)$ at a given ethane conversion of $11 \%$. Even at high conversion level of $63 \%$, the selectivity of ethylene retained at $80 \%$, which is competitive with the energy-demanding industrialized steam cracking route. A long-term test for $200 \mathrm{~h}$ resulted in stable conversion and product selectivity, showing the excellent catalytic stability. Both experimental and computational studies have identified that the hydrogen abstraction of B-OH groups by molecular oxygen dynamically generated the active sites and triggered ethane dehydrogenation.
\end{abstract}

(C) 2017, Dalian Institute of Chemical Physics, Chinese Academy of Sciences. Published by Elsevier B.V. All rights reserved.

because of the favorable thermodynamic and kinetic characters, for example, exothermic, lower reaction temperature, faster reaction rate, and almost no coking [5,6]. In the past decades, this reaction has widely developed using the metal-based catalysts [7-9]. To date, the catalytic systems that could offer good performance mainly include $\mathrm{Pt} / \mathrm{Sn}$, $\mathrm{SrFeO}_{3-\delta} \mathrm{Cl}_{\sigma}, \mathrm{Mg} / \mathrm{Dy} / \mathrm{Li} / \mathrm{Cl} / \mathrm{O}$, and $\mathrm{MoVTeNbO}_{x} \quad[2,4,10,11]$. However, deep-oxidation over these metal-based catalysts caused significant decrease in the selectivity of ethylene [12]. Nanostructured carbon materials, representing one type of metal-free catalysts, have been shown as a competitive system in the ODH of hydrocarbons, but with very low conversion of ethane and propane at the temperature up to $500{ }^{\circ} \mathrm{C}[13,14]$. It is most likely that in the case of $\mathrm{ODH}$ of ethane, typically operating at $500-700{ }^{\circ} \mathrm{C}$, carbon materials are fatally oxidized to $\mathrm{CO}_{2}$.

\footnotetext{
* Corresponding author. Tel/Fax: +86-411-84986112; E-mail: anhuilu@dlut.edu.cn

\# Corresponding author. Tel/Fax: +86-010-88236066; E-mail: dwang@ihep.ac.cn

This work was supported by the National Natural Science Foundation of China (21225312, U1462120, 21473206) and Cheung Kong Scholars Programme of China (T2015036).

DOI: 10.1016/S1872-2067(17)62786-4 | http://www.sciencedirect.com/science/journal/18722067 | Chin. J. Catal., Vol. 38, No. 2, February 2017
} 
Boron nitride, also a type of metal-free catalysts, is characterized by the excellent structural and thermal stability under oxidative atmospheres [15,16]; and it has been demonstrated, quite recently, to selectively and efficiently catalyze the $\mathrm{ODH}$ of propane to propylene in the temperature up to $500{ }^{\circ} \mathrm{C}$ [17]. Independently, our group demonstrated that hydroxlated boron nitride can selectively oxidize propane to propylene with long reaction stability ad extremely low $\mathrm{CO}_{2}$ formation [18]. As the ODH of ethane typically operates at higher temperatures than that of propane, catalysts with outstanding high-temperature oxidation resistance become the crucial issue. Herein, we report that hydroxylated boron nitride (BNOH) can efficiently catalyze the ODH of ethane to ethylene, offering rather high selectivity of ethylene (up to 95\%) and excellent stability for 200-h test.

\section{Experimental}

\subsection{Catalyst preparation}

The boron nitride was hydroxylated by a sodium-assisted high-temperature steam activation process. Initially, sodium nitrite solution ( $\left.200 \mu \mathrm{L}, 1 \mathrm{~mol} \mathrm{~L}^{-1}\right)$ was incipient impregnated into boron nitride $(1.0 \mathrm{~g})$, followed by calcination in air at 560 ${ }^{\circ} \mathrm{C}$ for $1 \mathrm{~h}$. The solid product was then treated at $530{ }^{\circ} \mathrm{C}$ with 5 vol\% $\mathrm{H}_{2} \mathrm{O} / \mathrm{N}_{2}$ for $3 \mathrm{~h}$. Sodium ions were further leached out with a reflux in $3 \mathrm{~mol} \mathrm{~L}^{-1}$ ammonia at $80{ }^{\circ} \mathrm{C}$ for 3 times, followed extensive washing with ultrapure water (40 times, 50 $\mathrm{mL}$ water each). The obtained powders were treated in air at $500{ }^{\circ} \mathrm{C}$ for $2 \mathrm{~h}$. The obtained sample was named as BNOH.

\subsection{Catalytic evaluation}

Catalytic reactions were performed in a fixed-bed microreactor. The feed consists of $\mathrm{C}_{2} \mathrm{H}_{6} / \mathrm{O}_{2} / \mathrm{N}_{2}$ with a molar ratio of $1 / 1 / 4$, and flow rate of reaction gas was fixed at $48 \mathrm{~mL} \mathrm{~min}^{-1}$. The reaction temperature was varied in $550-610^{\circ} \mathrm{C}$. The reaction products were analyzed by online gas chromatograph equipped with a TCD. A GDX-102 and molecular sieve 5A column were used to analyze the $\mathrm{O}_{2}, \mathrm{~N}_{2}, \mathrm{C}_{2} \mathrm{H}_{6}, \mathrm{C}_{2} \mathrm{H}_{4}, \mathrm{CH}_{4}, \mathrm{CO}$, and $\mathrm{CO}_{2}$. In kinetic analysis, the dependence of ethane conversion on reaction temperature was evaluated to calculate the apparent activation energy. Effect of contact time on reaction rate and product distribution was measured by varying reactant flow rates. Reaction orders were obtained by evaluating the effect of reactant partial pressure on reaction rates.

Conversion was defined as the number of moles of carbon converted divided by the number of moles of carbon present in the feed. Selectivity was defined as the number of moles of carbon in the product divided by the number of moles of carbon reacted. The carbon balance was checked by comparing the number of moles of carbon in the outlet stream to the number of moles of carbon in the feed. Under our typical evaluating conditions, the carbon balance was within $\pm 5 \%$. In order to account for the volume expansion in the reaction, nitrogen was used as the internal standard.

\subsection{Catalyst characterization}

X-ray diffraction (XRD) were measured on a PANalytical Model X'Pert 3 Powder diffractometer using $\mathrm{Cu} K_{\alpha}$ radiation $(\lambda$ $=0.15406 \mathrm{~nm})$. High-resolution transmission electron microscope (TEM) measurements were performed on an FEI F30 microscope. Solid-state ${ }^{1} \mathrm{H}$ nuclear magnetic resonance (NMR) spectra were recorded on an Agilent DD2-500 MHz spectrometer at $499.8 \mathrm{MHz}$ using a 4-mm MAS NMR probe with a spinning rate of $10 \mathrm{kHz}$. The chemical shifts were referenced to tetramethylsilane (TMS). Prior to testing, the sample was dehydrated at $400{ }^{\circ} \mathrm{C}$ for $1 \mathrm{~h}$ at $10^{-4} \mathrm{~Pa}$. X-ray photoelectron spectroscopy (XPS) analysis was carried out on Thermo VGE SCALAB250 analyzer. Monochromatic Al K X-ray source (1486.6 eV, anode operating at $15 \mathrm{kV}$ and $150 \mathrm{~W}$ ) was used as incident radiation. The binding energy of the element was calibrated using an C $1 s$ photoelectron peak at $284.5 \mathrm{eV}$. Fourier transform infrared spectra (FT-IR) were recorded on a Nicolet 6700 FT-IR spectrometer equipped with a quartz transmission cell. The gas composition at the reactor outlet during FT-IR experiments was controlled by online mass spectrometry (Pfeiffer, OminStar ${ }^{\mathrm{TM}}$ ). Isotope-labelling experiments were carried out in a fixed bed microreactor. Initially, BNOH was treated at $590^{\circ} \mathrm{C}$ in $\mathrm{He}\left(40 \mathrm{~mL} \mathrm{~min}^{-1}\right)$ for 1 $\mathrm{h}$, and then a 12-h H/D exchange was performed in a $3.5 \mathrm{vol} \%$ $\mathrm{D}_{2} \mathrm{O} / \mathrm{He}$ stream. The $\mathrm{BNOH}$ after exchange was further purged using the dry $\mathrm{He}$ for $3 \mathrm{~h}$. Subsequently, $\mathrm{C}_{2} \mathrm{H}_{6}, \mathrm{O}_{2}$ or a mixture of the two ( $800 \mu \mathrm{L}$ each time) was pulsed into the deuterated $\mathrm{BNOH}$ with $\mathrm{He}$ as the carrier gas. The chemical and isotopic compositions of the reactor effluent were measured by online mass spectrometry.

\subsection{Computational details}

All stationary points were fully optimized using the B3LYP hybrid exchange-correlation functional as implemented in Gaussian 09 program with all atoms described by a double $\xi$ quality basis set, 6-31G(d, p), followed by vibrational frequency analysis to identify the nature of the stationary points, either as minima or transition states. Intrinsic reaction coordinate (IRC) calculations were carried out to confirm that each transition state connects the two minima along the reaction pathway.

\section{Results and discussion}

ODH of ethane was performed in a packed-bed quartz microreactor under atmospheric pressure using a feed gas containing ethane, oxygen and nitrogen (1:1:4). The BNOH catalyst afforded surprisingly high selectivity and yield toward ethylene. For example, the selectivity to ethylene was as high as $95 \%$ at $11 \%$ ethane conversion, the byproduct consisted of CO (4.7\%) and $\mathrm{CO}_{2}(0.4 \%)$ (Fig. 1(a)). As the conversion of ethane was increased to $\sim 40 \%$, the selectivity of ethylene still was kept at $90 \%$, which was superior to that over most of metal and metal oxide catalysts [7]. As further increasing the conversion of ethane to $63 \%$ by raising the reaction temperature, the selectivity of ethylene only slightly lowered to $80 \%$, correspond- 

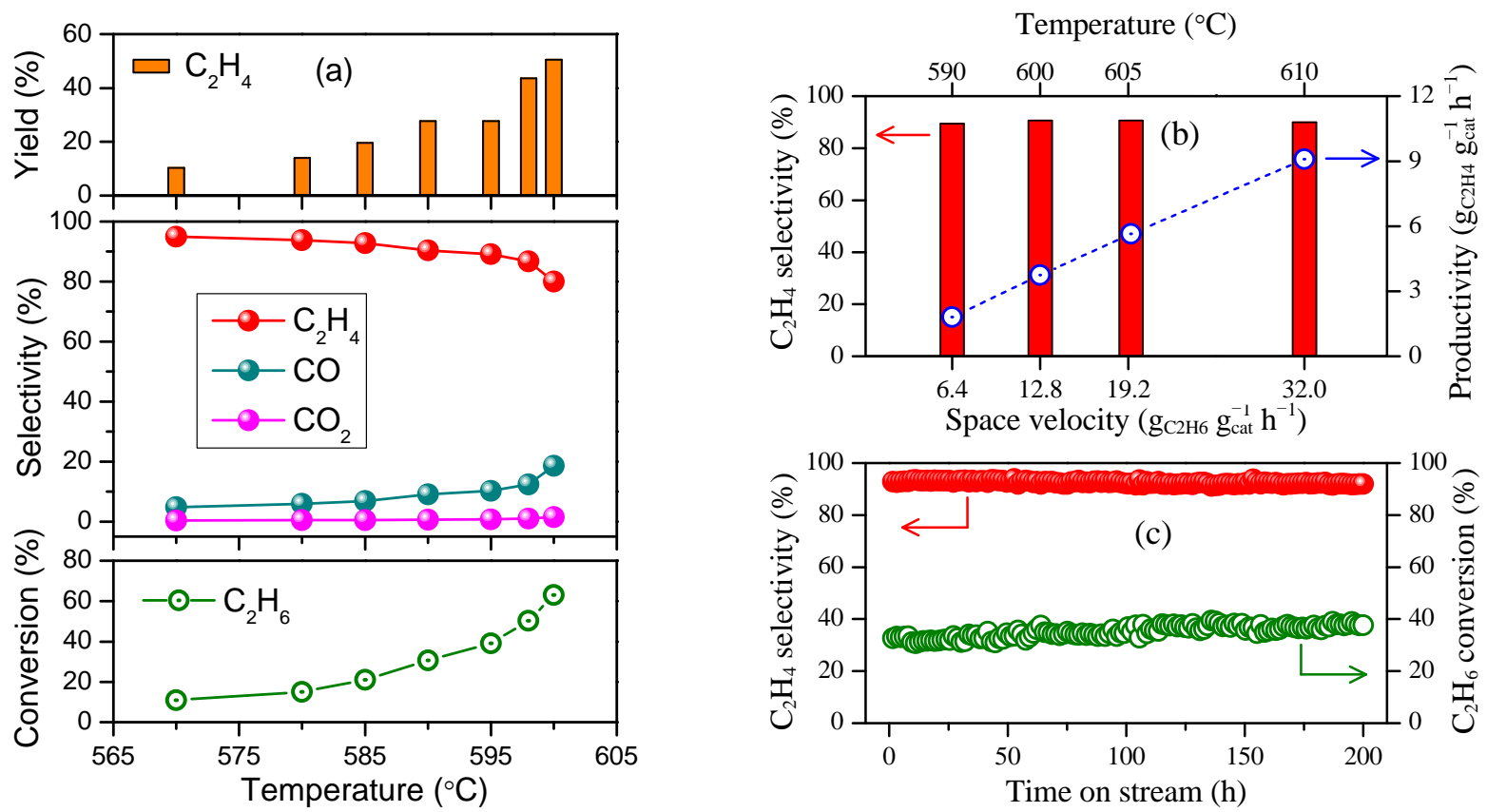

Fig. 1. ODH of ethane over the BNOH catalyst. (a) Dependence of ethane conversion, ethylene selectivity and yield on the reaction temperature; (b) Effect of space velocity and reaction temperature on the productivity of ethylene; (c) Long-term stability test at $590{ }^{\circ} \mathrm{C}$. Reaction conditions: catalyst, $100 \mathrm{mg}$; gas feed, 16.7 vol\% $\mathrm{C}_{2} \mathrm{H}_{6}, 16.7$ vol\% $\mathrm{O}_{2}$, and $\mathrm{N}_{2}$ balance; $570-610{ }^{\circ} \mathrm{C}$; space velocity $6.4-32.0 \mathrm{~g}_{\mathrm{c} 2 \mathrm{H} 6} \mathrm{~g}_{\mathrm{cat}}{ }^{-1} \mathrm{~h}^{-1}$.

ing to an ethylene yield of $\sim 50 \%$. This outstanding performance renders $\mathrm{BNOH}$ a comparable system with well-developed ethane steam cracking process in view of the $\sim 85 \%$ selectivity to ethylene at $\sim 60 \%$ conversion of ethane, but much superior considering the much lower reaction temperature and $\mathrm{CO}_{2}$ emission [2].

Notably, only negligible amount of $\mathrm{CO}_{2}$, as the over-oxidation product, was formed over the BNOH catalyst even when ethane conversion reached 63\% (Fig. 1(a)), clearly showing the excellent performance of the current BNOH catalyst in selective activation of the $\mathrm{C}-\mathrm{H}$ bond in ethane. The effect of contact time on product distribution in ethane ODH further revealed that ethylene was the only primary product at the near-zero contact time, while selectivity to the byproduct $\mathrm{CO}$ approached to zero, evidencing that the $\mathrm{BNOH}$ catalyst intrinsically avoids the cleavage of $\mathrm{C}-\mathrm{C}$ in ethane under the $\mathrm{ODH}$ conditions.

The BNOH catalyst also can afford high ethylene productivity, (i.e., grams of $\mathrm{C}_{2} \mathrm{H}_{4}$ formed per gram of catalyst per hour). As shown in Fig. 1(b), an unprecedented ethylene productivity $\left(9.1 \mathrm{~g}_{\mathrm{C} 2 \mathrm{H} 4} \mathrm{~g}_{\mathrm{cat}^{-1}} \mathrm{~h}^{-1}\right)$ with $>90 \%$ selectivity was achieved over the BNOH catalyst by mediating the reaction conditions. Such

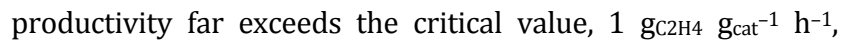
which would be commercially attractive [7]. The remarkable stability of the $\mathrm{BNOH}$ catalyst in the $\mathrm{ODH}$ of ethane was evidenced by the operation for $200 \mathrm{~h}$ at $590{ }^{\circ} \mathrm{C}$, during which no obvious variations in the conversion and product selectivity was detected (Fig. 1(c)), demonstrating its potential for industrial application.

Structure evolution of the BNOH catalysts before and after ODH of ethane was characterized. XRD pattern (Fig. 2(a)) showed that the BNOH catalyst still retained the typical hexagonal layered structure after a 200-h reaction. As observed by TEM, the morphology and lattice fringe of the spent BNOH catalyst kept similar as the original ones (Fig. 2(b)). XPS analysis revealed that 8.3 atom $\%$ surface oxygen present in the spent BNOH catalyst, slightly higher than that (6.9 atom\%) of the fresh one (Fig. 2(d)). Solid-state ${ }^{1} \mathrm{H}$ NMR spectra further revealed that the amount of $\mathrm{B}-\mathrm{OH}$ groups in the $\mathrm{BNOH}$ catalyst remained unchanged even after a 200-h reaction test (Fig. 2(c)). These results further confirm that the BNOH catalyst is stable under the ethane ODH reaction conditions.

Furthermore, we tracked the dynamic evolution of $\mathrm{B}-\mathrm{OH}$ groups under the ethane ODH reaction conditions using the FT-IR spectroscopy. As seen in Fig. 3(a), the characteristic band of hydroxyl stretching vibration was clearly observed at $\sim 3400$ $\mathrm{cm}^{-1}$ [17-20]. Upon exposure to $\mathrm{C}_{2} \mathrm{H}_{6}$ atmosphere at $590{ }^{\circ} \mathrm{C}$, the band position of the hydroxyl stretches remained unchanged (Fig. 3(a)), and no ethane conversion was detected. With the addition of molecular oxygen $\left(\mathrm{O}_{2} / \mathrm{C}_{2} \mathrm{H}_{6} / \mathrm{N}_{2}\right)$, however, the absorption of hydroxyl vibrational stretches gradually weakened (Fig. 3(a)), accompanied with the formation of ethylene, indicating that the $\mathrm{OH}$ groups interacted with molecular oxygen and incorporated into the reaction system. The intensities of hydroxyl vibrational stretches were recovered upon steam activation (Fig. 3(a)), suggesting that the $\mathrm{OH}$ groups could be readily regenerated.

Isotope-labelling experiments further confirmed the catalytic role of the $\mathrm{B}-\mathrm{OH}$ groups in ethane $\mathrm{ODH}$ reaction. When only $\mathrm{O}_{2}$ was pulsed into the deuterated $\mathrm{BNOH}(\mathrm{D})$ catalyst at $590{ }^{\circ} \mathrm{C}$, no species containing $\mathrm{H}$ or $\mathrm{D}$ atom were detected, suggesting that no activation of molecular oxygen occurred on the 

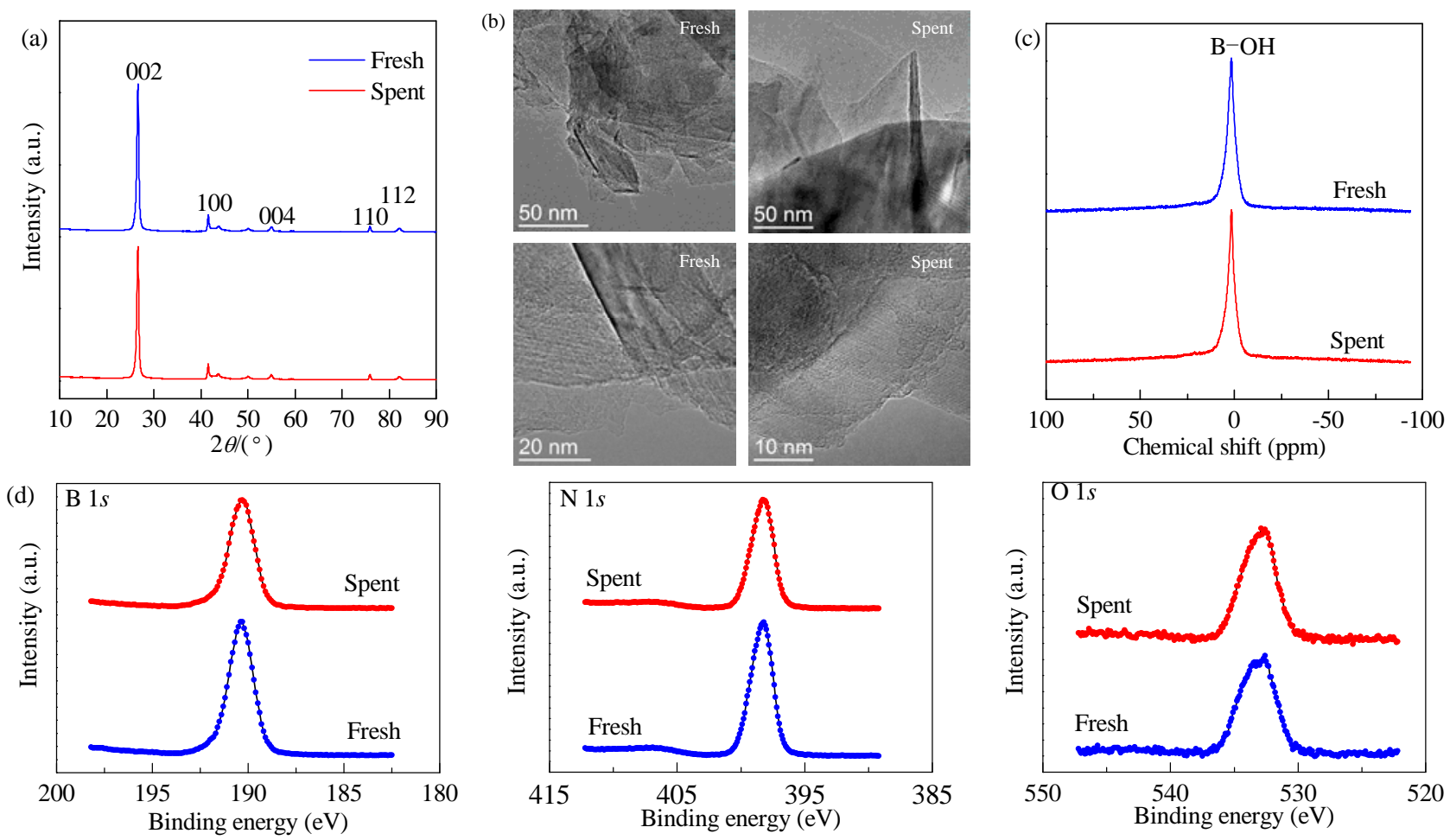

Fig. 2. XRD patterns (a), high-resolution TEM images (b), ${ }^{1} \mathrm{H}$ NMR spectra (c), and B $1 s, \mathrm{~N} 1 s$, and $01 s$ XPS spectra (d) of the fresh and spent BNOH catalyst after a 200 -h test.
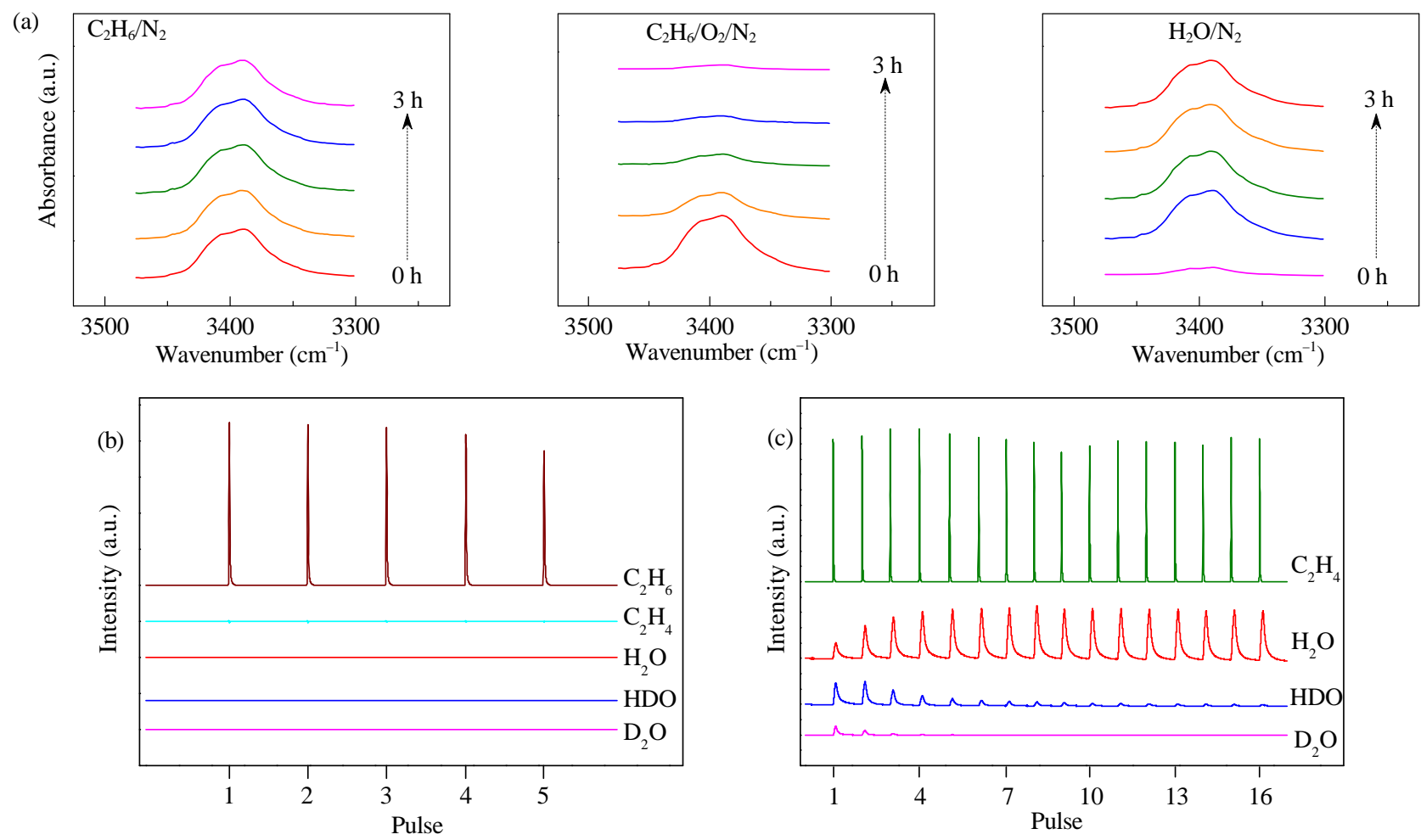

Fig. 3. (a) FT-IR spectra of $\mathrm{B}-\mathrm{OH}$ vibration over the BNOH catalyst under $\mathrm{C}_{2} \mathrm{H}_{6}, \mathrm{C}_{2} \mathrm{H}_{6} / \mathrm{O}_{2} / \mathrm{N}_{2}$ and $\mathrm{H}_{2} \mathrm{O} / \mathrm{N}_{2}$ atmospheres at $590{ }^{\circ} \mathrm{C}$. Mass spectra of $\mathrm{C}_{2} \mathrm{H}_{4}$, $\mathrm{H}_{2} \mathrm{O}$, $\mathrm{HDO}$ and $\mathrm{D}_{2} \mathrm{O}$ species upon pulsing $\mathrm{C}_{2} \mathrm{H}_{6}$ (b) or a mixture of $\mathrm{C}_{2} \mathrm{H}_{6}$ and $\mathrm{O}_{2}$ (c) onto the deuterated $\mathrm{BNOH}$ (D) catalyst at $590{ }^{\circ} \mathrm{C}$.

surface B-OH(D) group. Similarly, no product appeared as well when only pulsing $\mathrm{C}_{2} \mathrm{H}_{6}$ into the deuterated $\mathrm{BNOH}(\mathrm{D})$ catalyst (Fig. 3(b)), indicating no chemical interaction between $\mathrm{C}_{2} \mathrm{H}_{6}$ and surface B-OH(D) groups, and revealing the bridging oxygen bonded at the $\mathrm{BNOH}$ edge being unreactive for the ethane $\mathrm{C}-\mathrm{H}$ activation. In contrast, when a mixture of $\mathrm{C}_{2} \mathrm{H}_{6}$ and 

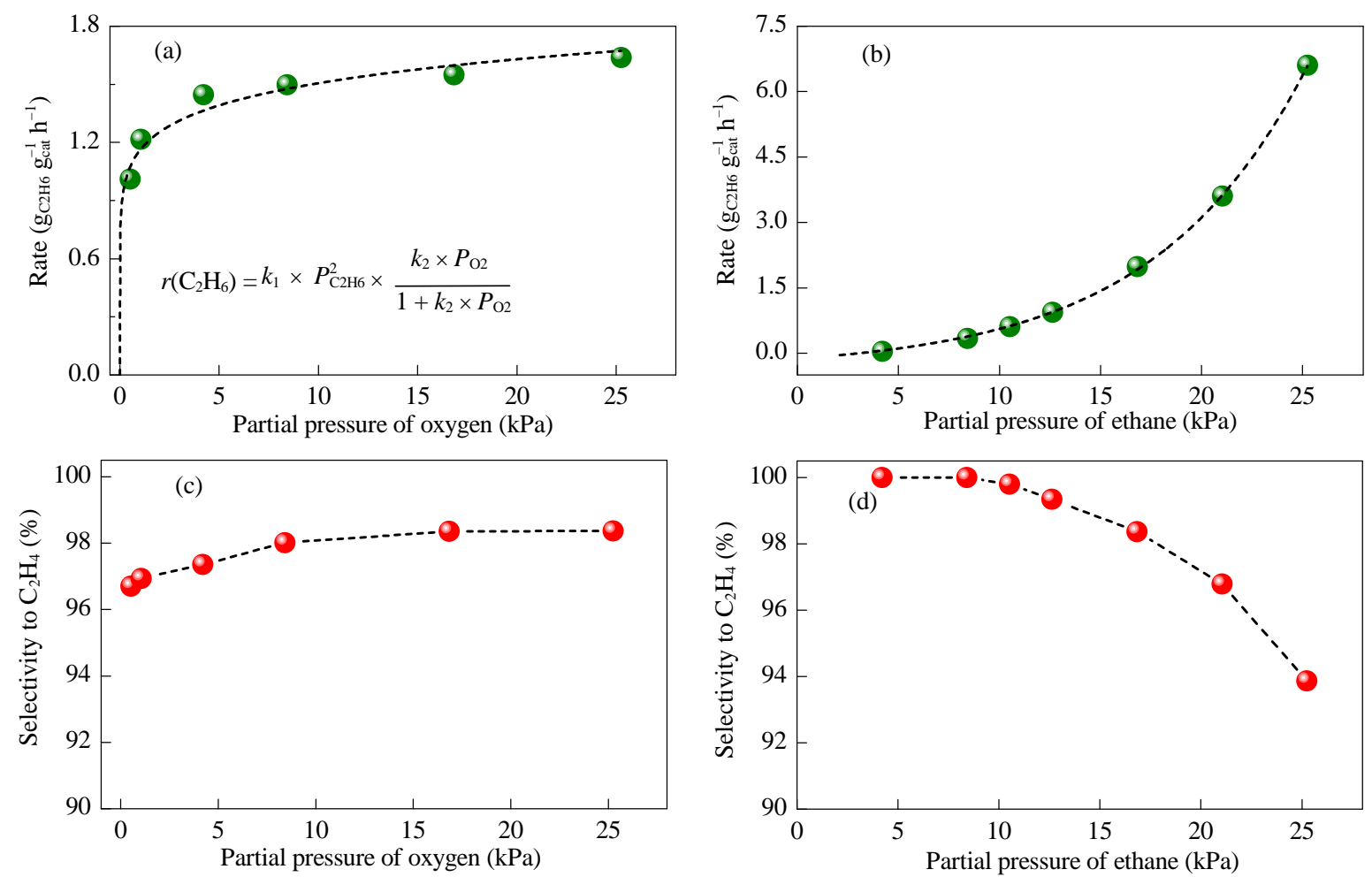

Fig. 4. Effect of partial pressures of oxygen and ethane on the converting rate of ethane (a,b), and the selectivity to ethylene (c,d) in ODH of ethane over the BNOH catalyst. Reaction conditions: catalyst $100 \mathrm{mg}$; gas feed $0-25.2$ vol $\% \mathrm{C}_{2} \mathrm{H}_{6}, 0-25.2$ vol\% $\mathrm{O}_{2}$, and $\mathrm{N}_{2}$ balance; $590{ }^{\circ} \mathrm{C}$; space velocity 12.8 $\mathrm{g}_{\mathrm{C} 2 \mathrm{H} 6} \mathrm{~g}_{\mathrm{cat}}{ }^{-1} \mathrm{~h}^{-1} ; 0.1 \mathrm{MPa}$.

$\mathrm{O}_{2}$ was pulsed into the reaction chamber, besides the formation of ethylene and $\mathrm{H}_{2} \mathrm{O}$, both $\mathrm{HDO}$ and $\mathrm{D}_{2} \mathrm{O}$ were also generated immediately (Fig. 3(c)), clearly indicating that the H/D atoms in the BNOH(D) catalyst were abstracted during the $\mathrm{ODH}$ reaction process. In subsequent pulses, the intensities of $\mathrm{HDO}$ and $\mathrm{D}_{2} \mathrm{O}$ gradually decreased whilst the intensity of $\mathrm{H}_{2} \mathrm{O}$ increased (Fig. 3(c)). This experiment verified the dynamic exchange between the $\mathrm{H}$ atoms in ethane and the edge of $\mathrm{BNOH}$ catalyst and the $\mathrm{B}-\mathrm{OH}$ groups as the active sites.

In line with this, kinetic experiments were performed to obtain deep insights on the reaction pathway of ethane ODH over the BNOH catalyst. Fig. 4 shows the effect of reactant concentrations on the converting rate of ethane. Langmuir-type (L-type) dependence on oxygen concentration corresponds with a reaction mechanism controlled by $\mathrm{O}_{2}$ activation on the catalyst surface (Fig. 4(a)), which is consistent with the observations by FT-IR and isotope-labelling experiments. The second-order dependence on ethane concentration suggested that gaseous ethane might react directly with the activated oxygen species on the catalyst surface (Fig. 4(b)). The increase in selectivity as increasing oxygen concentration (Fig. 4(c) and (d)) reveals that molecular oxygen favors the formation of ethylene. The apparent activation energy of ethane was estimated to be $241.7 \mathrm{~kJ} \mathrm{~mol}^{-1}$. These kinetic behaviors are intrinsically different from traditional metal oxide catalysts which typically follow the Mars-Van Krevelen mechanism [21,22].

Based on catalytic, spectroscopic and kinetic data, density functional theory (DFT) calculations were further performed to understand the underlying possible reaction pathway. All computational details and results were presented in Fig. 5. Based on the experimental studies, the hydroxylated boron nitride was considered as the resting state of the catalyst. In the presence of $\mathrm{O}_{2}$ at high temperature, the edge $\mathrm{B}-\mathrm{OH}$ groups may be dehydrogenated by $\mathrm{O}_{2}$, leading to the generation of two radical species, $\mathrm{BNO}^{\bullet}$ and $\mathrm{HO}_{2}{ }^{\bullet}$ radicals with a free energy barrier of $2.06 \mathrm{eV}$ and endothermicity of $1.80 \mathrm{eV}$. The $\mathrm{BNO}^{\circ}$ radical displays reactivity towards the hydrogen abstraction of ethane to produce $\mathrm{C}_{2} \mathrm{H}_{5}{ }^{\circ}$ radical. The free energy barrier was calculated to be $0.10 \mathrm{eV}$ and the reaction is exothermic by $0.54 \mathrm{eV}$. The subsequent dehydrogenation of $\mathrm{C}_{2} \mathrm{H}_{5}{ }^{\bullet}$ radical, either by $\mathrm{O}_{2}$ or $\mathrm{H}_{2} \mathrm{O}_{2}$, offers the primary product, $\mathrm{C}_{2} \mathrm{H}_{4}$. Along this pathway, the

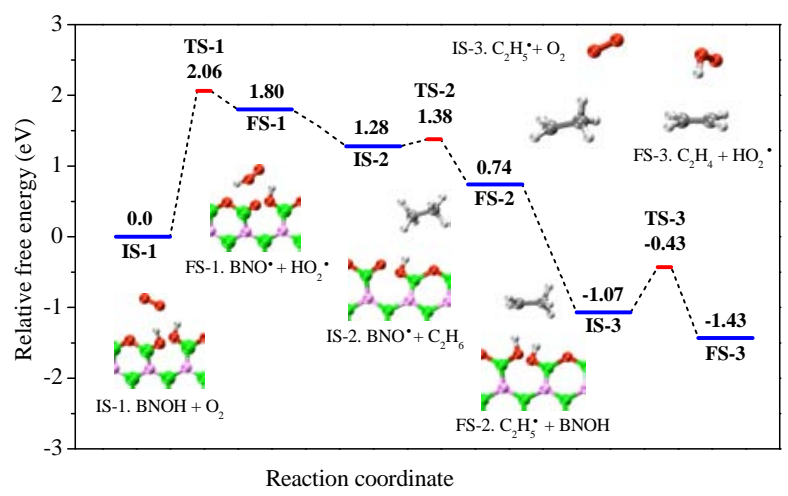

Fig. 5. Free energy profile of ODH of ethane catalyzed by BNOH from DFT calculations (IS: initial state; TS: transition state; FS: final state). Green represented boron, pink for nitrogen, red for oxygen, dark grey for carbon and light grey for hydrogen. 


\section{Graphical Abstract}

Chin. J. Catal., 2017, 38: 389-395 doi: 10.1016/S1872-2067(17)62786-4

\section{Selective oxidative dehydrogenation of ethane to ethylene over a hydroxylated boron nitride catalyst}

Lei Shi, Bing Yan, Dan Shao, Fan Jiang, Dongqi Wang *, An-Hui Lu*

Dalian University of Technology; Institute of High Energy Physics, Chinese Academy of Sciences

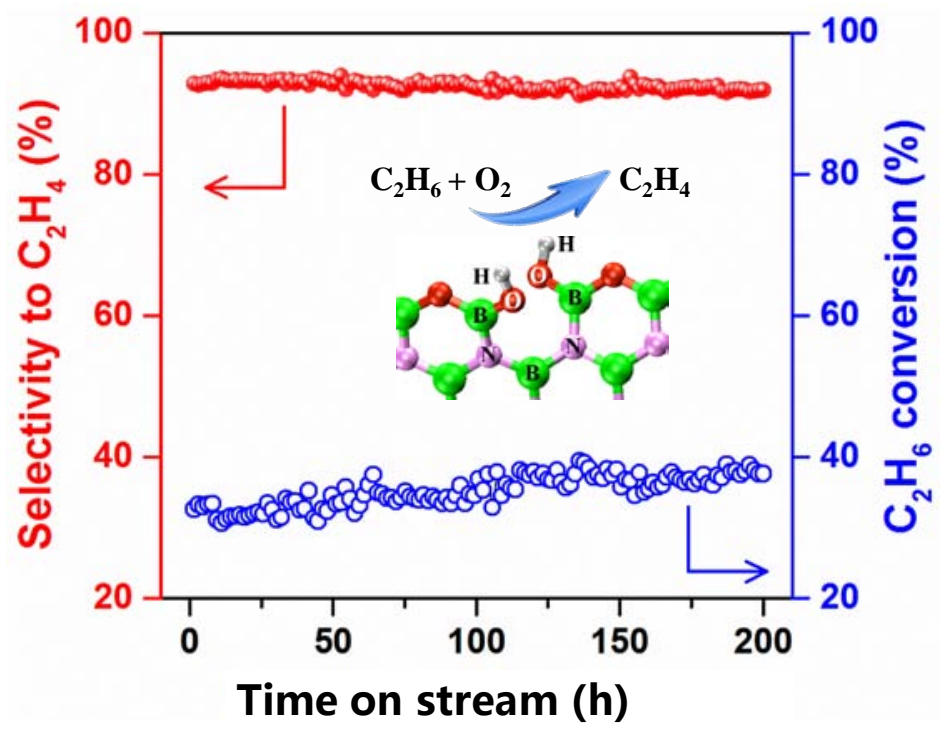

Hydroxylated boron nitride, a metal free catalyst, shows superior selectivity and excellent stability for the oxidative dehydrogenation of ethane to ethylene with only negligible $\mathrm{CO}_{2}$ emission.

dehydrogenation of the $\mathrm{B}-\mathrm{OH}$ sites appears as the rate-determining step. The $\mathrm{HO}_{2}{ }^{\bullet}$ radical, either formed by the oxidation of $\mathrm{BNOH}$ or $\mathrm{C}_{2} \mathrm{H}_{5}{ }^{\circ}$, may also be involved in the dehydrogenation of ethane via a free energy barrier of $0.93 \mathrm{eV}$. Accordingly, molecular oxygen plays crucial role in the ODH of ethane. It first abstracts one $\mathrm{H}$ atom from the $\mathrm{BNOH}$ to generate the $\mathrm{BNO}^{\circ}$ active species and triggers the ODH of ethane, and it may also react with $\mathrm{C}_{2} \mathrm{H}_{5}{ }^{\bullet}$ to assist the formation of ethylene. This explains the L-type $\mathrm{O}_{2}$-dependence observed in kinetic experiments (Fig. 4(a)). As seen in Fig. 4(a), (c), (d), increasing the partial pressure of $\mathrm{O}_{2}$ favours the conversion of ethane and the selectivity to ethylene, suggesting the participation of $\mathrm{O}_{2}$ in the consumption of the $\mathrm{C}_{2} \mathrm{H}_{5}{ }^{\circ}$ intermediate to produce ethylene when sufficient amount of $\mathrm{O}_{2}$ is present in the reaction chamber. Moreover, the activation pathway of ethane with edge $\mathrm{BNO}^{\bullet}$ and surface $\mathrm{HO}_{2}{ }^{\bullet}$ species nicely support the second-order rate dependence with respect to ethane concentrations in the ODH reaction over the $\mathrm{BNOH}$ catalyst (Fig. 4(b)).

\section{Conclusions}

We demonstrate that boron nitride upon hydroxylation exhibits a superior selectivity to ethylene but only small amount of $\mathrm{CO}_{2}$ formation in oxidative dehydrogenation of ethane. Based on experimental and computational studies, a possible reaction pathway was proposed that the hydrogen abstraction of B-OH groups by molecular oxygen dynamically generated the active sites, and triggered ethane dehydrogenation. This novel met- al-free catalyst system enriches our knowledge on catalytic activation of alkanes and serves as a promising catalyst for the industrial ODH process.

\section{References}

[1] https://www.ihs.com/products/chemical-technology-pep-coal-to -olefins-2011.html.

[2] A. S. Bodke, D. A. Olschki, L. D. Schmidt, E. Ranzi, Science, 1999, $285,712-715$.

[3] H. Zimmermann, R. Walzl, in: Ullmann's Encyclopedia of Industrial Chemistry, Wiley-VCH Verlag GmbH \& Co. KGaA, Weinheim, 2000.

[4] C. A. Gartner, A. C. van Veen, J. A. Lercher, ChemCatChem, 2013, 5, 3196-3217.

[5] R. Grabowski, Catal. Rev.-Sci. Eng., 2006, 48, 199-268.

[6] M. M. Bhasin, J. H. McCain, B. V. Vora, T. Imai, P. R. Pujado, Appl. Catal. A, 2001, 221, 397-419.

[7] F. Cavani, N. Ballarini, A. Cericola, Catal. Today, 2007, 127, 113-131.

[8] M. A. Bañares, Catalysis Today, 1999, 51, 319-348.

[9] Q. J. Ge, B. Zhaorigetu, C. Y. Yu, W. Z. Li, H. Y. Xu, Catal. Lett, 2000, $68,59-62$.

[10] H. X. Dai, C. F. Ng, C. T. Au, Catal. Lett., 1999, 57, 115-120.

[11] P. Botella, E. García-González, A. Dejoz, J. M. L. Nieto, M. I. Vázquez, J. González-Calbet, J. Catal., 2004, 225, 428-438.

[12] C. A. Gärtner, A. C. van Veen, J. A. Lercher, J. Am. Chem. Soc., 2014, 136, 12691-12701.

[13] W. Qi, D. S. Su, ACS Catal., 2014, 4, 3212-3218.

[14] B. Frank, M. Morassutto, R. Schomäcker, R. Schlögl, D. S. Su, ChemCatChem, 2010, 2, 644-648. 
[15] R. T. Paine, C. K. Narula, Chem. Rev., 1990, 90, 73-91.

[16] Q. H. Weng, X. B. Wang, Y. Bando, D. Golberg, Chem. Soc. Rev., 2016, 45, 3989-4012.

[17] J. T. Grant, C. A. Carrero, F. Goeltl, J. Venegas, P. Mueller, S. P. Burt, S. E. Specht, W. P. McDermott, A. Chieregato, I. Hermans, Science, 2016, 354, 1570-1573.

[18] L. Shi, D. Q. Wang, W. Song, D. Shao, W.-P. Zhang, A.-H. Lu, ChemCatChem, DOI: $10.1002 /$ cctc.201700004.
[19] A. Bhattacharya, S. Bhattacharya, G. P. Das, Phys. Rev. B: Condens. Matter, 2012, 85, 035415/1-035415/9.

[20] T. Sainsbury, A. Satti, P. May, Z. Wang, I. McGovern, Y. K. Gun'ko, J. Coleman, J. Am. Chem. Soc., 2012, 134, 18758-18771.

[21] F. Cavani, F. Trifirò, Catal. Today, 1999, 51, 561-580.

[22] C. A. Carrero, R. Schlögl, I. E. Wachs, R. Schomaecker, ACS Catal. 2014, 4, 3357-3380.

\section{羟基化氮化硼催化乙烷氧化脱氢制乙烯

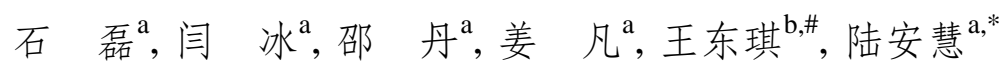 \\ a大连理工大学化化工学院, 精细化工国家重点实验室, 辽宁大连 116024 \\ ${ }^{\mathrm{b}}$ 中国科学院高能物理研究所多学科研究中心, 北京 100049}

摘要: 乙烯是最为重要的化工原料之一, 目前其工业来源主要来自于烃类的水蒸汽裂解过程. 该过程本质上是一个高 温均相裂解过程, 温度 $\left(>800{ }^{\circ} \mathrm{C}\right)$ 高, 能耗大, 碳排放严重. 乙烷氧化脱氢制乙烯属于放热反应, 反应温度低, 速率快, 无积碳 等限制, 是一条更富有竞争力的工艺路线. 然而, 常用的金属或金属氧化物催化剂容易导致乙烯深度氧化, 从而降低了乙 烯选择性. 纳米碳材料在烃类氧化脱氢反应中展现出一定的催化活性, 但容易被氧化, 难以用于反应温度高的乙烷氧化脱 氢反应.

本文报道了羟基化的氮化硼(BNOH)可高效催化乙烷氧化脱氢制乙烯. 氮化硼边沿羟基官能团脱氢生成了动态活性 位, 从而引发了乙烷的脱氢反应. BNOH对乙烷氧化脱氢制乙烯显示出高选择性. 当乙烷转化率在 $11 \%$, 乙烯选择性可高达 95\%; 当乙烷转化率增加到 $40 \%$, 乙烯选择性保持在 $90 \%$. 重要的是, 当乙烷转化率超过 $60 \%$ 时, BNOH仍然可保持 $80 \%$ 的乙 烯选择性以及 $50 \%$ 的乙烯收率. 这些性能指标与现有工业乙烷水蒸气裂解过程运行性能相当. 进一步优化反应条件, BNOH催化剂能够实现高达 $9.1 \mathrm{~g}_{\mathrm{C} 2 \mathrm{H} 4} \mathrm{~g}_{\mathrm{cat}}^{-1} \mathrm{~h}^{-1}$ 的时空收率. 经过 $200 \mathrm{~h}$ 的氧化脱氢反应测试, BNOH催化剂活性和选择性基 本恒定, 表明其具有非常好的稳定性. X射线粉末衍射结果显示, 反应前后BNOH催化剂的物相没有发生变化. 透射电子显 微镜测试证实, 反应后BNOH催化剂的形貌和微观结构也没有明显改变. X射线光电子能谱结果显示, 反应200 hr后BNOH 催化剂表面的氧含量仅从反应前的 6.9 atom\%微增到 $8.3 \mathrm{atom} \% .{ }^{1} \mathrm{H}$ 固体核磁共振谱测试显示, 反应 $200 \mathrm{~h}$ 后, BNOH催化剂 上羟基含量无明显改变. 结合原位透射红外光谱和同位素示踪实验, 初步确定了BNOH催化剂上引发乙烷氧化脱氢反应的 活性中心. 氮化嗍边沿的氧官能团并不能引发乙烷的氧化脱氢反应, 而羟基官能团才是氧化脱氢反应发生的活性位. 在乙 烷氧化脱氢条件下, 分子氧脱除羟基官能团上的氢原子动态生成 $\mathrm{BNO}^{*}$ 和 $\mathrm{HO}_{2}{ }^{*}$ 活性位. 密度泛函理论计算表明, 乙烷首先在 $\mathrm{BNO}^{*}$ 或 $\mathrm{HO}_{2}$ 位活化生成乙基自由基, 这些中间物进一步与气相氧物种发生反应脱氢生成乙烯. 动力学测试结果也验证了 上述实验和理论结果.

关键词: 氮化硼; 差基化; 乙烷; 氧化脱氢; 乙烯

收稿日期: 2017-01-09. 接受日期: 2017-01-18. 出版日期: 2017-02-05.

*通讯联系人. 电话/传真: (0411)84986112; 电子信箱: anhuilu@dlut.edu.cn

\#通讯联系人. 电话: (010)88236606; 电子信箱: dwang@ihep.ac.cn

基金来源: 国家自然科学基金(21225312, U1462120, 21473206); 长江学者奖励计划(批准号T2015036).

本文的英文电子版由Elsevier出版社在ScienceDirect上出版(http://www.sciencedirect.com/science/journal/18722067). 